\title{
STUDI FENOMENOLOGI PENGALAMAN KELUARGA SUKU JAWA DENGAN ANGGOTA KELUARGA MENDERITA COVID-19 DI RUANG PERAWATAN INTENSIF
}

\author{
Moch. Bahrudin ${ }^{1)}$, Tanty Wulan Dari ${ }^{2}$ \\ ${ }_{1,2}$ Proram Studi Keperawatan, Poltekkes Kemenkes Surabaya, Surabaya, Indonesia \\ email: bahrudin_moch@yahoo.com
}

\begin{abstract}
Abstrak
Keputusasaan merupakan penilaian negatif terhadap hasil yang akan dicapai dan ketidakberdayaan terhadap suatu harapan. Keputusasaan dapat terjadi pada keluarga dengan salah anggotanya di rawat dengan COVID-19 di ruang perawatan intensif karena perasaan keputusasaan akibat suatu keadaan ketidakpastian serta waktu yang tidak dapat dipastikan dalam penyembuhannya. Kondisi ini dapat berlanjut pada gangguan mental emosional maupun tindakan suicide. Oleh karena itu gambaran pengalaman keluarga pasien yang di rawat di ruang perawatan intensif dibahas dalam penelitian ini. Penelitian kualitatif deskriptif fenomenologi terhadap 6 partisipan yang bersuku jawa. Hasil penelitian didapatkan tujuh tema utama yaitu (1) Perpisahan sebagai akibat pasien perlu pengawasan, (2) Respon keputusasaan, (3) Disfungsi proses keluarga, (4) Kehilangan makna hidup, (5) Dukungan dan motivasi diri sebagai sumber koping menghadapi keputusasaan, (6) Hikmah spiritual dibalik keputusasaan stroke survivor dan (7) Dapat menjalani kehidupan dengan lebih baik. Penelitian ini menyarankan dikembangkannya standar asuhan keperawatan keputusasaan dan pemberian dukungan keluarga pasien yang dirawat diruang perawatan intensif khususnya pada rumah umum milik daerah di suku Jawa.
\end{abstract}

Kata kunci: COVID-19, keputusasaan, kualitatif

\begin{abstract}
Hopelessness is a negative assessment toward the results to be achieved and the helplessness of a hope. Hopelessness can occur in families with one of their members is hospitalized because of COVID-19 in Intensive Care Unit because of hopelessness feelings due to uncertain time of recovery. This condition can lead to mental emotional disorders or suicide. The purpose of this study is to provide an overview of the family experiences of patients with covid 19 who are hospitalized in Intensive Care Unit. Phenomenological descriptive qualitative research on 6 Javanese participants. The results of the study found seven main themes, namely (1) Separation as a result of patients need supervision, (2) Hopelessness response, (3) Dysfunction of the family process, (4) Loss of meaningful life, (5) Support and selfmotivation as a source of coping in facing hopelessness, (6) Spiritual wisdom behind the hopelessness of stroke survivors and (7) Being able to live a better life. This study suggests the development of nursing care standards for hopelessness and providing family support for patients who are hospitalized in Intensive Care Unit, especially in regional public hospitals in the Javanese tribe.
\end{abstract}

Keywords: COVID-19, hopelessness, qualitative

\section{PENDAHULUAN}

Perpisahan keluarga dengan anggota keluarga yang di rawat diruang perawatan intensif merupakan akibat konsekuensi yang harus dijalani oleh keluarga memerlukan suatu penanganan khusus untuk proses penyembuhan yang lama dan berdampak terhadap kondisi psikososial perawatan intensif survivor. Terjadinya perubahan psikososial, seperti perasaan harga diri yang rendah, perasaan tidak beruntung, perasaan ingin mendapatkan kembali kemampuan yang menurun, berduka, takut dan putus asa merupakan manifestasi dari keputusasaan bahkan tanda dari depresi. Menurut Albal, E., \& Kutlu, Y. (2010) keputusasaan pada hakekatnya merupakan precursor dalam perjalanan depresi (Albal, E., \& Kutlu, 2010).

Perawatan intensif yang dialami keluarga dengan anggotanya mengalami COVID-19 yang 
dirawat diruang intensif, akan dapat berlanjut ke kondisi keputusasaan, depresi bahkan tindakan suicide (bunuh diri). Teasdale, T. W., \& Engberg, A. W. (2010) menjelaskan perawatan intensif survivor beresiko mengalami tindakan keputusasaan (Teasdale, 2001). Kondisi ini menyebabkan keputusasaan sangat beresiko mengalami gangguan mental emosional.

Disisi lain perawatan intensif pada pasien COVID-19 dengan keputusasaan membutuhkan penanganan jangka pendek untuk mengembangkan mekanisme koping yang adaptif dan mencegah berkembangnya stressor disabilitas menjadi kondisi maladaptif.

Upaya antisipasi menurunkan angka keputusasaan adalah dengan mengelola keluarga pasien yang mempunyai risiko mengalami gangguan mental emosional supaya tidak mengalami masalah gangguan jiwa, salah satunya adalah keluarga perawatan intensif survivor dengan keputusasaan. Berdasarkan fenomena tersebut penting untuk dilakukan kajian yang mendalam terhadap perawatan intensif survivor dengan masalah psikososial keputusasaan. Oleh karena itu, penelitian ini ingin menjawab pertanyaan "Bagaimanakah pengalaman keputusasaan perawatan intensif survivor pada keluarga dengan copvid-19 suku jawa di Kota Sidoarjo?"

\section{METODE PENELITIAN}

Desain penelitian ini menggunakan penelitian kualitatif fenomenologi deskriptif. Partisipan penelitian ini adalah keluarga pasien dengan salah satu anggotanya mengalami COVID-19 yang dirawat di ruang intensif dengan riwayat lebih dari 3 hari, pengalaman 1 kali, usia dewasa pertengahan (40-60 tahun), pernah mempunyai pengalaman keputusasaan kategori sedang yang diukur dengan skor Beck Hopelessness Scale (BHS) dan gangguan kognitif ringan yang dilihat dengan skor Mini Mental State Examination (MMSE). Jumlah sampel yang berpartisipasi pada penelitian ini enam orang. Tempat penelitian di kota Sidoarjo bulan April sampai dengan Juni 2020.

Pengumpulan data dilakukan dengan wawancara mendalam (indepth interview) dan catatan lapangan. Analisis data menggunakan langkah-langkah Colaizzi, dengan membuat transkripsi verbatim, membaca trankrip secara berulang-ulang, mengumpulkan penyataan signifikan, menentukan arti setiap pernyataan yang penting, mengumpulkan kata kunci, mengelompokkan ke dalam kategori, kemudian disusun dan dikelompokkan menjadi tema hasil penelitian.

\section{HASIL DAN PEMBAHASAN}

Partisipan dalam penelitian ini adalah Perawatan intensif survivor, dengan empat orang berjenis kelamin laki-laki dan dua orang berjenis kelamin perempuan dengan usia antara 40 sampai 55 tahun dan berstatus menikah. Tingkat pendidikan partisipan terdiri atas SMA, Diploma III dan Sarjana. Lama perawatan anggota keluarga di ruang perawatan intensif antara 3 sampai 5 hari dengan empat orang mengalami orang tua yang dirawat di ruang intensif dan dua orang partisipan bahwa yang dirawat adalah anaknya. Keseluruhan perawatan intensif survivor pernah mempunyai pengalaman keputusasaan sedang dan mempunyai kognitif baik.

Didapatkan berbagai pengalaman Perawatan intensif survivor dalam menghadapi keputusasaan dalam 7 tema utama.

\section{a. Hasil}

\section{Perubahan peran akibat respon keputusasaan}

Perubahan peran yang diungkapan sebagai akibat dari keputusasaan adalah perasaan fatique seperti lemas dan tidak bertenaga seperti ungkapan partisipan berikut:

"Rasanya saat saya down seperti tidak mempunyai kekuatan, seluruh badan yang lemes tambah lemes....." (P1)

Akibat yang dirasakan partisipan lain adalah merasa letih dan penurunan kemampuan kerja fisik dengan contoh ungkapan dibawah ini:

"Terus terang badan saya sepertinya loyo, tenaganya kok hilang, kekuatan badan saya tambah lemas, tidak ada semangat dan kondisi fisik saya menurun atau dwon." (P4)

Akibat keputusasaan juga dirasakan dalam gangguan pemenuhan nutrisi dan gangguan tidur sebagaimana ungkapan partisipan berikut ini:

"Biasanya kan saya kalau pagi itu rasanya sarapan walaupun seadanya saya makan sama minum air putih, tapi waktu itu pas saya dwon saya setiap mau makan rasanya kenyang, nafsu makan tidak ada sampai sampai istri seperti marah.” (P4)

Gangguan tidur diungkapkan seperti:

“.......terus terang saat saya serangan lagi, kemudian perasaan putus asa saya muncul beberapa mala mini saya tidak tidur rasanya 
tidak kantuk, itu bisa sampai 2 hari, saat mau tidur kepikir terus kalau saya jadi merepotkan." (P5)

Akibat keputusasaan mempengaruhi perfusi cerebral dengan rasa pusing seperti ungkapan berikut ini:

"Kondisi pas saya semangatnya hilang, sepertinya (berkunang- kunang seperti mau pingsan) sama pusing pak.” (P3)

\section{Respon perpisahan dengan anggota keluarga sebagai stressor keputusaan}

Respon perpisahan diungkapkan partisipan dengan ketidakpercayaan atau tawar menawar sebagaimana ungkapan berikut ini:

"Mengapa kok sudah 2 hari ini papa saya dirawat dan saya tidak boleh menunggui". (P4)

Respon perpisahan dalam dirinya berusaha diatasi dengan menekan (supresi) permasalahan yang dihadapi seperti yang diungkapkan partisipan:

"Saya gak mau ngomong sama istri kasihan nanti kalau malah kepikiran istri saya." (P1)

Selain itu partisipan juga mengungkapkan marah atas kondisinya

"Kadang-kadang tangan dan kaki kanan saya, saya pukul-pukulkan di dipan bagaimana sih kok saya tidak boleh menunggui anak saya yang sakit." (P5)

Perilaku depresi seperti perpisahan, perasaan sedih, serta khawatir diungkapkan sebagai berikut:

"Anak anak saya masih kecil, sementara saya tidak bisa bekerja, pokoknya sepertinya saya sudah menyerah.” (P4)

"Sepertinya kok seperti ini rasanya sedih, kuatir, pak saya jadi malas melakukan apa-apa, saya cuma menangis." (P3)

\section{Tidak bersemangat makna hidup}

Ketidakberdayaan dalam mancapai tujuan hidup dimaknai sebagai hilangnya makna hidup bahkan muncul keinginan mengakhiri hidupnya seperti ungkapan berikut:

"Ya saya kan perempuan, suami saya kerja kalau sebelumnya saya bisa membantu kerja di pabrik masak, bersih bersih rumah tetapi sekarang saya dirumah sakit terus menunggui ibu saya, malah jadi merepotkan suami saya..........” (P3)
"Di pikiran saya muncul kalau memang bapak waktunya meninggal dunia atau diambil nyawa saya tidak apa-apa saya kasihan sama suami dan anak anak repot." (P5)

\section{Disfungsi peran dalam keluarga}

Pengalaman disfungsi peran dalam keluarga yang dialami partisipan disebabkan ketidakmampuan dalam menjalankan fungsi anggota keluarga memberikan penghargaan bagi anggota keluarganya, sebagaimana diungkapkan sebagai berikut:

"Sempat waktu itu anak saya bilang tidak enak ke saya, saya bilang pada anak mau saya pukul tapi saya masih sadar, bahkan sempat ingin saya bunuh, terus terang." (P1)

Sedangkan ketidakmampuan memberikan penghargaan antar anggota keluarga diungkapkan sebagai berikut:

"Kalau di rumah saya minta bantuan sama anak saya memasak air untuk mandi saya kadang-kadang anak saya itu tidak langsung mau, nunggu di suruh sampai beberapa kali, tapi sekarang saya tergantung pada perawat." (P3)

\section{Dukungan dan motivasi diri sebagai sumber koping menghadapi keputusasaan}

Sumber koping Perawatan COVID-19 survivor berasal dari dukungan keluarga, lingkungan, keyakinan diri serta motivasi untuk aktivitas. Sumber koping dari keluarga inti sebagaimana diungkapkan :

"Anak saya yang kuliah waktu itu kebetulan libur kalau pas saya menjaga di rumah sakit terus menemani saya terus kemudian bilang ibu sabar tabah, terus suami ya ngasih semangat, nah kalau anak dan bilang suami memberi semangat saya rasanya semangat hidup muncul lagi." (P5)

Selain dukungan keluarga keyakinan atau semangat dari dalam diri stroke survivor diungkapkan seperti berikut:

"Tapi yang perlu ketahui pokoknya ya semangat dari dalam diri sendiri, pas waktu itu saya parkir mau terima uang jatuh, kan tangan kanan saya masih belum seperti sekarang saya diomelin pokoknya dikata-katain, saya tidak peduli sampai sekarang itu yang terus saya ingat." (P2) 
Hikmah spiritual dibalik keputusasaan Perawatan COVID-19 survivor

Perawatan COVID-19 survivor mendapatkan hikmah atau makna hidup kembali melalui proses memaknai ulang akan nilai-nilai spiritual dalam kondisi ketidakberdayaannya dan makna terhadap dirinya seperti berikut ini:

"Saya bersyukur, sebetulnya saya mungkin ditunjukan ke jalan yang lebih terang dan hikmah yang paling mendalam saya diberi kesempatan untuk beribadah memperbaiki hidup.” (P3)

"Sejak saya pernah down sampai sekarang saya bisa bekerja semampu saya menjadikan saya lebih sabar." (P4)

\section{Dapat menjalani kehidupan dengan lebih baik}

Makna dibalik keputusasaannya partisipan mendorong partisipan untuk berkeinginan mempunyai harapan hidup yaitu kembali sembuh dan sehat, dapat menjalankan fungsi perannya sebagaimana ungkapan berikut:

"Harapan saya sembuh, bisa cari rongsoknya lancar, terus anak anak seha.t”(P4)

\section{b. Pembahasan}

\section{Karakteristik partisipan}

Keputusasaan dalam proses perjalanannya masih terdapat perdebatan dalam hal penyebabnya, penelitian ini menunjukan manifestasi keputusasaan terjadi pada COVID-19 survivor dengan hemiplegi dektra pada empat partisipan. Penelitian lain menyebutkan bahwa terdapat hubungan antara perpisahan dengan anggota keluarga dengan tingkat stress keluarga (Naess, Lunde and Brogger, 2012).

Dua partisipan mengalami hal ini menunjukan bahwa keputusasaan tidak hanya disebabkan oleh faktor organik akan tetapi dapat disebabkan karena faktor reaksi psikologis sebagai konsekuensi klinis akibat COVID-19.

Karakteristik partisipan penilitian ini masih belum menggambarkan pengalaman keputusasaan dari individu yang tidak mempunyai sistem pendukung seperti suami, istri serta pengalaman di tinggalkan orang yang dicintai.

\section{Tema perubahan fisik sebagai akibat respon keputusasaan}

Perubahan fisik akibat keputusasaan antara lain fatique, anoreksia serta insomnia. Perasaan fatique diungkapkan partisipan seperti ekstremitas tambah lemas dan perasaan loyo tidak bertenaga.
Menurut Naess, H., Lunde, L., \& Brogger, J. (2012). perasaan fatique berhubungan dengan adanya nyeri dan depresi klien pasca stroke. Hasil penelitiannya menyebutkan terdapat tiga manifestasi yang sering muncul pada klien stroke yaitu depresi $19 \%$, fatique sebanyak $46 \%$ dan nyeri sebesar $48 \%$. Berdasarkan korelasinya antara depresi dan fatique menunjukan hubungan yang kuat sedangkan antara nyeri dan depresi mempunyai hubungan yang sedang (Naess, Lunde and Brogger, 2012).

Pengalaman nyeri COVID-19 survivor tidak didapatkan dalam penelitian ini, menurut peneliti hal ini dimungkinkan pengaruh dari faktor budaya. Budaya Jawa khususnya di Jawa Tengah mengungkapkan nyeri pada orang lain dapat bermakna mengganggu orang yang diajak mengungkapkan nyerinya tersebut. Faktor lain yang dapat mempengaruhi adalah usia. Menurut Kozier, Erb, Berman, \& Snyder (2010) orang dewasa dapat mengabaikan rasa nyeri karena mengakui rasa nyeri dapat dianggap sebagai tanda kelemahan atau kegagalan (Kozier, Erb, Berman, 2010).

\section{Respon kehilangan sebagai stressor keputusasaan}

Klien paska COVID-19 merasakan kehilangan kemampuan fungsional karena penyakit yang dapat mengubah citra tubuhnya. Pada kondisi ini klien stroke mendapatkan stressor yang menyebabkan klien tersebut mempunyai harapan negatif dan muncul ketidakberdayaan terhadap harapannya tersebut. Hal ini sejalan dengan penelitian pada penyakit kronik seperti kanker payu dara yang menyebutkan $80 \%$ mempunyai perasaan khawatir akan masa depannya, $30 \%$ merasakan ketakutan (Gumus, A. B., Cam, O., \& Malak, 2011).

Hasil penelitian ini terungkap bahwa respon kehilangan COVID-19 survivor sudah tidak pada tahap penolakan (denial) akan tetapi masuk pada tahap marah, hal ini sebagai bentuk perasaan frustasi dengan kondisi ketidakberdayaan dalam menjalankan peran dirinya. Marah yang diungkapkan pada COVID-19 survivor ini sebenarnya merupakan salah satu bentuk koping dirinya. Selain marah COVID-19 survivor melakukan koping dengan supresi yaitu permasalahan yang ada pada dirinya tidak mau diceritakan pada orang lain. Bertambahnya jumlah stresor dapat menyebabkan tahapan kehilangan klien membutuhkan waktu yang lebih lama untuk sampai pada kondisi acceptance. 


\section{Dukungan dan motivasi diri sebagai sumber koping menghadapi keputusasaan}

Sumber koping yang menjadi pilihan utama COVID-19 survivor pada kondisi keputusasaan adalah dukungan keluarga dalam hal ini keluarga inti yaitu istri, suami atau anak-anaknya. Significant other dinilai mempunyai makna dan arti penting dalam menumbuhkan COVID-19 survivor dengan keputusasaan. Hal tersebut didukung hasil penelitian lain kualitatif yang dilakukan Jones, L., \& Morris, R. (2013) tentang pengalaman stroke survivor usia dewasa dan karir orang tua didapatkan tema penelitian "significant parent" yang menjelaskan bahwa dukungan saat merawat dirasakan paling natural adalah orang tua $\mathrm{ibu}$, ayah, anak atau pasangannya (Jones and Morris, 2013).

Usaha COVID-19 survivor untuk tetap semangat dilakukan melalui usaha untuk menumbuhkan keyakinan internal diri, dan motivasi untuk beraktivitas agar terbebas dari keputusasaannya. Keyakinan internal diri atau positive belief ini biasa disebut juga sebagai self efficacy. Menurut Bandura (1997) dalam Stuart, G. W., \& Laraia, M. T. (2014) Self Efficacy merupakan kapabilitas dari kepercayaan diri individu. Individu yang mempunyai self efficacy yang tinggi akan memberikan efek terhadap pemikiran, motivasi, suasana hati serta kesehatan fisik individu tersebut sehingga stressor dianggap sebagai tantangan (Stuart, G. W., \& Laraia, 2014). Penelitian Albal, E., \& Kutlu, Y. (2010) menjelaskan terdapat hubungan antara koping self efficacy dan sosial support pada klien depresi, dimana klien dengan depresi mempunyai skor self efficacy yang rendah (Albal, E., \& Kutlu, 2010).

Peranan sosial support dalam membantu mengatasi keputusasaan dalam penelitian ini juga ditemukan. Panzarella, C., Alloy, L. B., \& Whitehouse, W. G. (2006) menjelaskan sosial support merupakan bagian dari adaptive inferential feedback (AIF) yang bekerja menurunkan sesitifitas kognitif depresi dengan menurunkan kesimpulan negatif individu, selain itu juga menurunkan perilaku maladaptive sebagai hasil dari kesimpulan negatif dari pengalaman yang menyebabkan keputusasaan (Panzarella, Alloy and Whitehouse, 2006).

\section{Hikmah spiritual dibalik keputusasaan COVID- 19 survivor}

Menurut Bastaman, H. D. (2007). makna hidup dapat ditemukan dalam setiap keadaan yang menyenangkan dan tidak menyenangkan, keadaan bahagia, dan penderitaan, ungkapan seperti "makna dalam penderitaan" (meaning in suffering) atau "hikmah dalam musibah" (blessing in disguise) (Bastaman, 2007). Makna hidup stroke survivor didapatkan melalui proses memaknai ulang terhadap nilai-nilai spiritual bagi dirinya. Penelitian ini mengungkapkan perbedaan dengan penelitian terdahulu pada penyakit kronis yang dilakukan oleh Srivastava, A., Taly, A. B., Gupta, A., \& Murali, T. (2010) dimana makna spiritual pada penelitiannya didapat pada saat kondisi acceptance sedangkan stroke survivor dengan keputusasaan makna hidupnya diperoleh dalam kondisi ketidakberdayaan menuju ke kondisi acceptance (Srivastava et al., 2010). Pengalaman partisipan ini merupakan manifestasi perjalanan tahapan kehilangan sebagaimana dijelaskan sebelumnya bahwa setiap individu tidak sama dalam melalui suatu proses kehilangan. Ada yang bisa langsung mencapai fase penerimaan ada yang sangat lama bahkan berbulan-bulan untuk akhirnya dapat menerima kondisi sakitnya (Yosep, 2010). Penelitian lain dilakukan oleh Wachholtz dan Pearce (2009 dalam Liu, R. T., Kleiman, E. M., Nestor, B. A., \& Cheek, S. M. (2015) menjelaskan bahwa peranan spiritualitas dalam penyakit konis dan kecacatan dapat mendorong klien menemukan perasaan positif pada dirinya (Liu et al., 2015).

\section{KESIMPULAN DAN SARAN}

Hasil penelitian menunjukan bahwa dampak dari keputusasaan COVID-19 survivor antara lain mengalami perubahan fisik sebagai akibat respon keputusasan, terjadi respon kehilangan sebagai stressor keputusasaan, disfungsi proses keluarga, serta kehilangan makna hidup. Hasil penelitian kehilangan makna hidup menambah temuan pengalaman baru yaitu keinginan untuk mengakhiri hidup dan dapat menjadikan domain penting dalam menentukan kualitas hidup stroke survivor dalam hal psycological being khususnya dalam kontrol diri.

Munculnya dampak dari keputusasaan, COVID-19 survivor melakukan pilihan dan strategi koping antara lain dukungan dari keluarga dan lingkungan. Dukungan keluarga inti bagi COVID19 survivor merupakan significant others dalam menghadapi keputusasannya. Hasil penelitian ini juga menggambarkan bahwa pengalaman keputusasaan klien COVID-19 berhubungan erat dengan proses adaptasi klien saat mendapat stressor baik fisik maupun stresor psikologis. Proses tersebut melibatkan beberapa fungsi antara lain fungsi fisiologis, konsep diri, peran maupun interdependensi yang dapat dimaknai sebagai support sistem. 
Perlu kiranya terapi kognitif yang telah dikembangkan di Keperawatan medical bedah dilakukan modifiksi dengan menambahkan sesi tentang membangun harapan positif. Sesi ini akan dapat membangkitkan motivasi dan harga diri klien dengan keputusasaan.

\section{REFERENSI}

Albal, E., \& Kutlu, Y. (2010) 'The Relationship Between the Depression Coping Self-Efficacy Level and Perceived Social Support Resources Depresyonla Başa Çıkma Öz Yeterlik Düzeyi ile Algilanan Sosyal Destek Arasındaki İlişki', Journal of Psychiatric Nursing, 1(3), pp. 115120.

Bastaman, H. D. (2007) Logoterapi : psikologi untuk menemukan makna hidup dan meraih hidup bermakna. Jakarta: Raja Grafindo Persada.

Gumus, A. B., Cam, O., \& Malak, A. T. (2011) 'Relationships between psychosocial adjustment and hopelessness in women with breast cancer', Asian Pasific Journal of Cancer Prevention, 12(2), pp. 433-438.

Jones, L. and Morris, R. (2013) 'Experiences of adult stroke survivors and their parent carers: a qualitative study', Clinical Rehabilitation, 27(3), pp. 272-280. doi: $10.1177 / 0269215512455532$.

Kozier, Erb, Berman, \& S. (2010) Buku Ajar Fundamental Keperawatan: Konsep, Proses, \& Praktik. Jakarta: EGC.
Liu, R. T. et al. (2015) 'The Hopelessness Theory of Depression: A Quarter-Century in Review', Clinical Psychology: Science and Practice, 22(4), pp. 345-365. doi: 10.1111/cpsp.12125.

Naess, H., Lunde, L. and Brogger, J. (2012) 'The Triad of Pain, Fatigue and Depression in Ischemic Stroke Patients: The Bergen Stroke Study', Cerebrovascular Diseases, 33(5), pp. 461-465. doi: 10.1159/000336760.

Panzarella, C., Alloy, L. B. and Whitehouse, W. G. (2006) 'Expanded Hopelessness Theory of Depression: On the Mechanisms by which Social Support Protects Against Depression', Cognitive Therapy and Research, 30(3), pp. 307-333. doi: 10.1007/s10608-006-9048-3.

Srivastava, A. et al. (2010) 'Post-stroke depression: Prevalence and relationship with disability in chronic stroke survivors', Annals of Indian Academy of Neurology, 13(2), p. 123. doi: 10.4103/0972-2327.64643.

Stuart, G. W., \& Laraia, M. T. (2014) Principles and practice of psychiatric nursing. Canada: Mosby Elsevier.

Teasdale, T. W. (2001) 'Suicide after a stroke: a population study', Journal of Epidemiology \& Community Health, 55(12), pp. 863-866. doi: 10.1136/jech.55.12.863.

Yosep, I. (2010) Keperawatan Jiwa. Bandung: Refika Aditama. 